\title{
ISOLATION AND CHARACTERIZATION OF PLANT GROWTH PROMOTING RHIZOBACTERIA (PGPR) FROM RICE RHIZOSPHERE OF VARANASI AND EAST CHAMPARAN DISTRICT OF INDIA
}

\author{
Umesh Prasad Shrivastava
}

Department of Botany, TU, Thakur Ram Multiple Campus, Birganj, Nepal email: upshrivastava@gmail.com

\begin{abstract}
Keeping with objective to search efficient PGPR isolates, 46 bacterial isolates were isolated from the rhizosphere of 17 rice fields of two districts of India employing standard enrichment techniques using JNFb- solid agar medium. Among all isolates, ECI-10A showed highest nitrogenase activity $(1.72 \pm 0.09$ $\mu \mathrm{mol} \mathrm{C}_{2} \mathrm{H}_{4}$ formed/mg protein/h) and ECI-2A showed lowest activity (o.62 \pm $0.08 \mu \mathrm{mol} \mathrm{C}_{2} \mathrm{H}_{4}$ formed/mg protein/h). IAA production, P-solubilization and siderophore production were also tested among these isolates. Highest IAA production, $P$-solubilization and siderophore production were recorded in AF${ }_{7 C}(7.36 \pm 0.38 \mu \mathrm{g} / \mathrm{mg}$ dry weight), ECI-12A (188.65 $\pm 8.65 \mu \mathrm{g} / \mathrm{mg}$ dry weight) and $E C I-10 B(20.43 \pm 3.94 \mu \mathrm{g} / \mathrm{mg}$ dry weight) respectively; whereas, lowest in $A F-4 B(2.3 \pm 0.3 \mu \mathrm{g} / \mathrm{mg}$ dry weight $), A F-1 C(12.47 \pm 3.5 \mu \mathrm{g} / \mathrm{mg}$ dry weight) and $A F-4 B(1.45 \pm 2.32 \mu \mathrm{g} / \mathrm{mg}$ dry weight) respectively. Pseudomonas, Klebsiella, Azotobacter and Agrobacterium were predominantly present in the rhizosphere of rice plants of both districts of India is reported in present investigation.
\end{abstract}

\section{Keywords}

Plant growth promoting rhizobacteria; PGPR; Rhizosphere; Beneficial rhizobacteria; Acetylene reduction assay

\section{Introduction}

Plant-associated bacteria that are able to colonize roots are called rhizobacteria and can be classified into beneficial, deleterious, and neutral groups on the basis of their effects on plant growth. Beneficial rhizobacteria that stimulate plant growth are usually referred to as plant growth promoting rhizobacteria or PGPR (Glick, 1995). PGPR are a heterogeneous group of bacteria that can be found in the rhizosphere, at root surfaces and in association with roots. They can improve the extent or quality of plant growth by direct and/or indirect methods. In last few decades, a large array of bacteria including species of Pseudomonas, Azospirillum, Azotobacter, Klebsiella, Enterobacter, 
Alcaligens, Arthobacter, Burkholderia, Bacillus and Serratia have been isolated and reported to enhance plant growth (Glick, 1995; Okon and Labanderagonzalez, 1994). The direct plant growth promotion by PGPR entails either providing the plant with a plant growth promoting substances that are synthesized by the bacterium or facilitate the uptake of certain plant nutrients from the environment. The indirect promotion of plant growth occurs when PGPR minimize or prevent the deleterious effect of one or more phytopathogenic micro-organisms and help plants to fight against the environmental stresses. Several PGPR have been found successful in growth promotion in certain crops such as canola, soybean, lentil, pea, wheat and radish (Glick et al., 1997; Timmusk et al,, 1999). The enhancement of plant growth by PGPR indicates their potential as biofertilizers in the field of agriculture. Though the importance of PGPR is well understood, but efficient PGPR are lacking. Varanasi and East Champaran districts are better rice producing district in India but, screening of rhizobacteria for the search of efficient PGPR have not been done. Keeping this objective in mind the present investigation was performed and their plant growth promoting abilities were evaluated after screening and isolation of diazotrophic plant growth promoting rhizobacteria (PGPR) from the rhizosphere of rice plants of Varanasi and East Champaran districts of India.

\section{Materials and methods}

\section{Soil sample collection and isolation of} bacteria

Rice (Oryza sativa L.) plants of different fields of Varanasi and East Champaran districts of India were selected for the study. The locations of the fields showing latitude and longitude of the collection sites are shown in Table 1. Soil samples from rhizosphere of rice plants were collected carefully by uprooting the root system and placed in a sterile polythene bag for transport and stored at $4^{\circ} \mathrm{C}$. 1.0 gram of rhizospheric soil was suspended in $1.0 \mathrm{~mL}$ of sterile DDW in sterile test tube and was mixed properly. After $1 \mathrm{~h}$ of sedimentation, 1.0 $\mathrm{mL}$ of water was taken from the tube and it was mixed in another 9.0 mL of sterile DDW for dilution. 1.0 $\mathrm{mL}$ of bacterial suspension was further diluted in another sterile test tube containing 9.0 mL DDW. In this way it was diluted $10^{-7}$ dilution. $100 \mu \mathrm{L}$ of suspension was kept in solid $\mathrm{JNFb}^{-}$agar plate and spreading was done. It was incubated for 3 days at $30^{\circ} \mathrm{C}$ in BOD incubator and morphologically different colonies appeared on the plates were isolated, sub cultured and enriched in $\mathrm{JNFb}^{-}$medium (Döbereiner, 1995) devoid of combined nitrogen. The JNFb medium comprises $0.5 \%(\mathrm{w} / \mathrm{v})$ of Malic acid, $0.06 \%$ $(\mathrm{w} / \mathrm{v})$ of $\mathrm{K}_{2} \mathrm{HPO}_{4}, 0.18 \%(\mathrm{w} / \mathrm{v})$ of $\mathrm{KH}_{2} \mathrm{PO}_{4}$, $0.02 \%(\mathrm{w} / \mathrm{v})$ of $\mathrm{MgSO}_{4} .7 \mathrm{H}_{2} \mathrm{O}, 0.01 \%(\mathrm{w} / \mathrm{v})$ of $\mathrm{NaCl}, 0.02 \%(\mathrm{w} / \mathrm{v})$ of $\mathrm{CaCl}_{2} .2 \mathrm{H}_{2} \mathrm{O}, 0.0002 \%$ $(\mathrm{w} / \mathrm{v})$ of $\mathrm{Na}_{2} \mathrm{MO}_{4} .2 \mathrm{H}_{2} \mathrm{O}, 0.45 \%$ of $\mathrm{KOH}, 5$ $\mathrm{mL} / \mathrm{L}$ of bromothymol blue ( $0.5 \%$ in $0.2 \mathrm{~N}$ $\mathrm{KOH})$ and $4 \mathrm{~mL} / \mathrm{L}$ of Fe-EDTA (1.4\%).

\section{Acetylene reduction assay}

Nitrogenase activity was estimated by acetylene reduction assay (Stewart et al., 1967). Overnight LB medium grown cultures (1.5 mL) was spun and washed carefully with sterilized DDW to remove sources of combined nitrogen, if any, and then suspended in $100 \mu \mathrm{L}$ of PBS (phosphate-buffered saline). $10 \mu \mathrm{L}$ from this inoculum was added in $3 \mathrm{~mL}$ semi-solid (0.15\% agar w/v) JNFb medium in a $7 \mathrm{~mL}$ vacutainer tube (Becton-Dickinson, Rutherford, NJ, USA) and grown for 3 days. Thereafter pure acetylene gas was injected in each tube by a hypodermic syringe to attain $10 \%$ final concentration. All the assays were performed at $30^{\circ} \mathrm{C}$ without shaking. The ethylene formed was analyzed in a 5700 Nucon Gas Chromatograph (Nucon Engineers Ltd., New Delhi) fitted with Porapak R column and flame ionization detector. $\mathrm{N}_{2}$ was used as the carrier gas. Nitrogenase activity (acetylene reduction) was expressed in terms of $\mu$ moles $\mathrm{C}_{2} \mathrm{H}_{4} / \mathrm{mg}$ protein /h. 
ISOLATION AND CHARACTERIZATION OF PLANT GROWTH PROMOTING RHIZOBACTERIA (PGPR) FROM RICE RHIZOSPHERE OF VARANASI AND EAST CHAMPARAN DISTRICT OF INDIA

Test of IAA production by plate assay and estimation by colorimetric method

At first, the production of indole-3-acetic acid (IAA) was tested by IAA production plate assay (Shrivastava and Kumar, 2011). Thereafter, quantification of IAA was performed by colorimetric method of Gordon and Weber (1951). Cultures were grown in JNFb- liquid medium with or without tryptophan (100 $\mu \mathrm{g} / \mathrm{mL}$ ) at $30^{\circ} \mathrm{C}$ with shaking at $80 \mathrm{rpm}$ for three days. $1.5 \mathrm{~mL}$ culture was centrifuged at $8000 \mathrm{rpm}$ for $5 \mathrm{~min}$ at desired time interval and pellet was discarded and supernatant retained. To $1 \mathrm{~mL}$ supernatant, $2 \mathrm{~mL}$ IAA reagent $\left(1 \mathrm{~mL}\right.$ of $0.5 \mathrm{M} \mathrm{FeCl}_{3}$ was mixed in 50 $\mathrm{mL}$ of $35 \% \mathrm{HClO}_{4}$ ) was added. The sample was incubated at room temperature for $25 \mathrm{~min}$. The optical density of the samples was recorded at $530 \mathrm{~nm}$ (blank from respective medium was used). The amount of IAA was quantified with standard of pure IAA prepared separately.

\section{Test of phosphate solubilization}

All isolates were first screened on Goldstein agar plates for phosphate solubilization as described by Goldstein, 1987 (Goldstein and Liu, 1987). Quantitative analysis of phosphate solubilization was performed as per the method of Mehta and Nautiyal (2001). The test isolates were inoculated in Nautiyal phosphate solubilization broth. The Nautiyal medium comprises $1.0 \%(\mathrm{w} / \mathrm{v})$ glucose, $0.5 \%$ $(\mathrm{w} / \mathrm{v}) \quad \mathrm{Ca}_{3}\left(\mathrm{PO}_{4}\right)_{2}, \quad 0.5 \%(\mathrm{w} / \mathrm{v}) \quad \mathrm{MgCl}_{2}-6 \mathrm{H}_{2} \mathrm{O}$, $0.025 \%(\mathrm{w} / \mathrm{v}){ }^{4} \mathrm{MgSO}_{4}-7 \mathrm{H}_{2} \mathrm{O}, \quad 0.02 \%(\mathrm{w} / \mathrm{v})$ $\mathrm{KCl}$ and $0.01 \%(\mathrm{w} / \mathrm{v})\left(\mathrm{NH}_{4}\right)_{2} \mathrm{SO}_{4}$. The $\mathrm{pH}$ was adjusted 7.o. The culture was incubated for 3 days at $30 \pm 2^{\circ} \mathrm{C}$. The cultures were harvested by centrifugation at 10,000 rpm for $10 \mathrm{~min}$. The culture supernatant thus obtained was used for quantitative assays. The optical density was measured at $600 \mathrm{~nm}$ with spectrophotometer.

\section{Test of siderophore production}

The CAS (Chrome Azurol S) assay (Schwyn and Neilands, 1987) is the universal chemical assay for the detection of siderophore and is based on a siderophore's high affinity for ferric iron. CAS plates are blue in colour because chrome azurol S dye complex is formed with ferric iron. When siderophore is present, the following reaction occurs, which releases the free dye, which is orange in colour.

$$
\begin{aligned}
& \mathrm{Fe}^{3+} \text { - dye (blue) + siderophore } \rightarrow \\
& \mathrm{Fe}^{3+} \text { - siderophore + dye (orange) }
\end{aligned}
$$

Accordingly, CAS agar plates were prepared containing: $1 \mathrm{mM}$ Chromeazurol-S, $10 \mathrm{~mL}$ $\mathrm{FeCl}_{3} .6 \mathrm{H}_{2} \mathrm{O}(1 \mathrm{mM})$ made in $10 \mathrm{mM} \mathrm{HCl}$, and $\mathrm{N}$, N-cetyl trimethyl ammonium bromide (2 $\mathrm{mM})$ (CTAB). This was autoclaved separately and added to $300 \mathrm{~mL}^{\circ} \mathrm{JNFb}^{-}$medium containing $2 \mu \mathrm{M} \mathrm{FeCl}$ replacing the Fe-EDTA which is the usual ingredient of the medium. $10 \mathrm{~mL}$ of iron starved (JNFb- medium grown) culture was inoculated as spot inoculation on the CAS agar plate and incubated for $72 \mathrm{~h}$ at $30^{\circ} \mathrm{C}$. Yellow to orange halo zone appearing around the colonies was recorded as positive test for siderophore production.

\section{Estimation of siderophore concentration}

The isolates were grown in $\mathrm{JNFb}^{-}$liquid medium without any iron source to create iron starvation. Iron starved isolates were inoculated in $\mathrm{JNFb}^{-}$liquid medium containing $2 \mu \mathrm{M} \mathrm{FeCl}$ in place of Fe-EDTA. Estimation of siderophore was made after 3 days of incubation at $30^{\circ} \mathrm{C}$. For this culture supernatant was recovered by centrifugation at $8000 \mathrm{rpm}$ for $5 \mathrm{~min}$. $0.5 \mathrm{~mL}$ supernatant containing less than $7.5 \mathrm{nmol}$ of iron chelator was mixed with $0.5 \mathrm{~mL}$ of CAS assay solution. 2, 3-dihydroxybenzoic acid (DHBA) or catechol was used as positive control and un-inoculated medium as negative control. Absorbance was measured at $630 \mathrm{~nm}$.

\section{Biochemical characterization}

The Gram reaction was performed as per standard protocol. Physiological and biochemical characterizations of the bacterial isolates such as catalase, urease, nitrate reduction, IMViC and carbon source utilization were examined according to the standard methods (Benson, 1998). The isolates 
were identified accordance with the Bergey's manual of determinative bacteriology (Holt et al., 1994).

\section{Results and discussions}

\section{Isolation of diazotrophic rhizospheric bacteria}

Altogether 46 bacterial isolates were isolated from rhizospheric soil sample of different locations of 17 rice fields of different agroclimatic conditions and cultivation pattern of two districts of India employing standard enrichment techniques using JNFb- solid agar agar medium. All these isolates were routinely sub-cultured on solid JNFb agar-agar plates so as to ensure their diazotrophic character. When inoculum of dilutions was spread on to solid agar-agar $\mathrm{JNFb}^{-}$medium, a number of discrete colonies of bacteria appeared after 3-4 days of incubation. Maximum number ( 5 morphotypes) of morphologically distinct colonies was noted in the sample of B.H.U. Agricultures Farm, Varanasi of Varanasi district (AF-3) and the minimum (1) in the two samples of Semara of East Champaran district (ECI-1 and ECI-2) and other all samples showed 2, 3 or 4 morphotypes. Selection of various morphotypes was performed on the basis of size, shape, colour and elevation of colonies. Table 1 shows that out of 17 soil samples collected from different rice fields, the highest number of bacterial population $(28$ $\left.\mathrm{X} 10^{6}\right)$ was observed in the sample of Semara (ECI-1) and the lowest $\left(7.8 \mathrm{X} \mathrm{10}^{4}\right)$ in sample of B.H.U. Agricultures Farm namely AF-1. Table 2 $m$ shows acetylene reduction assay (nitrogenase activity) of all the isolates. It is evident from the results that the rate of nitrogenase activity differs significantly among all the isolates. Among all the isolates ECI-10A showed highest nitrogenase activity $(1.72 \pm 0.09$ $\mu \mathrm{mol} \mathrm{C}_{2} \mathrm{H}_{4}$ formed/mg protein/h) and the lowest activity was detected in ECI-2A ( 0.62 $\pm 0.08 \mu \mathrm{mol} \mathrm{C} \mathrm{C}_{2} \mathrm{H}_{4}$ formed/mg protein/h). It is interesting to note that the rate of nitrogenase activity varied markedly even in isolates obtained from the same locations. However results clearly show that all these isolates can fix $\mathrm{N}_{2}$ under reduced $\mathrm{O}_{2}$ tension though they are aerobic $\mathrm{N}_{2}$ fixers (Table 2).

In the present study, we have made an attempt to isolate diazotrophic bacteria from the rhizosphere of rice plants of different fields located Varanasi and East Champaran of India. It is evident from our results that there is presence of diverse types of diazotrophic bacteria in almost all the rice fields. The isolation and enrichment of diazotrophic bacteria were based on repeated growth in the medium devoid of any combined nitrogen sources. The bacterial colonies appearing on plates were differentiated and selected on the basis of morphological characters and it was observed that in general each soil sample contains 1 to 5 morphotypes of colonies. Presence of rhizobacteria with $\mathrm{N}_{2}$ fixation ability in the rhizosphere of various plants has been reported from various crop plants. A number of rhizospheric diazotrophs were isolated in the 1960s to 1970 s, but their contribution in the nitrogen nutrition is still under debate (Khalid et al. 2004). The specificity of the plant-bacteria interaction depends upon soil conditions, which can alter contaminant bioavailability, root exudates composition, and nutrient levels of the rhizosphere. Our study shows that the population size of bacteria of different rice fields differ which might be due to differences in genotypes of plants and partly due to soil types.

\section{Test of plant growth promoting activities}

IAA production, phosphate solubilization and siderophore production are considered to be the major plant growth promoting features of any bacteria. Accordingly tests for these characters were made in all the isolates. All the 46 isolates were tested for IAA production by the plate assay developed in our laboratory, only 31 isolates showed IAA positive result. It is evident from the data of Table 2 that out of 46 isolates, $31(67.4 \%)$ showed positive test for IAA production. IAA production occurred 
solely in liquid JNF- medium supplemented with tryptophan $(100 \mu \mathrm{g} / \mathrm{mL})$, there was no production in medium lacking tryptophan. With a view to optimize the concentration of tryptophan for IAA production, varying concentrations (ranging from 50 to $500 \mu \mathrm{g}$ / $\mathrm{mL}$ ) were used in the medium and it was observed that optimum IAA production was achieved at $100 \mu \mathrm{g} / \mathrm{mL}$. Among all the isolates AF-7C showed highest IAA production (7.36 $\pm 0.38 \mu \mathrm{g} / \mathrm{mg}$ dry weight) and AF-4B showed the lowest level $(2.3 \pm 0.3 \mu \mathrm{g} / \mathrm{mg}$ dry weight $)$ (Table 2).

Out of 46 isolates, $16(34.8 \%)$ produced halo-zones around the growing colony on Goldstein solid medium, whereas other $30(65.2 \%)$ either showed growth without any halo-zone formation or failed to grow. Efficiency of phosphate solubilization was further confirmed by measuring the level of solubilized $\mathrm{P}$ in the liquid Nautiyal medium (Table 2). It is evident that ECI-12A, an isolate from East Champaran district of India showed highest P solubilization $(188.65 \pm 8.65 \mu \mathrm{g} / \mathrm{mg}$ dry weight) and $\mathrm{AF}-1 \mathrm{C}$, an isolate from Varanasi district showed lowest P solubilization (12.47 $\pm 3.5 \mu \mathrm{g} / \mathrm{mg}$ dry weight).

Siderophore production was detected by means of CAS agar plate assay where blue colour of medium changed to yellow/orange around the growing colonies. On the basis of yellow/orange halo zone formation, 14 isolates (30.4\%) showed positive test for siderophore production. Quantitative estimation showed that the highest siderophore $(20.43 \pm 3.94$ $\mu \mathrm{g} / \mathrm{mg}$ dry weight) production occurs in the isolate ECI-10B whereas the lowest (1.45 \pm $2.32 \mu \mathrm{g} / \mathrm{mg}$ dry weight) level was in $\mathrm{AF}-4 \mathrm{~B}$ (Table 2).

Plant growth promoting tests of all these putative diazotrophic isolates revealed that 36 isolates showed at least one character i.e., IAA production, phosphate solubilization and siderophore production but 10 isolates failed to show any one of these three characters. Accordingly, 36 isolates showing plant growth promoting characteristics were selected for further study (Table 2). Bacterial isolates that produce relatively higher amount of IAA may affect root growth adversely; many plant pathogenic bacteria, viz., Pseudomonas savastonoi (Costacurta and Vanderleyden, 1995), Agrobacterium tumefaciens and $A$. rhizogenes (Zambryski et al., 1989), also produce phytohormones leading to pathogenesis. The bacteria reported in this study produced moderate range of IAA (2.3 to $7.36 \mu \mathrm{g} / \mathrm{mg}$ dry weight) and thus may be treated as potential PGPR. Plant growth promotion observed with bacteria that produce moderate levels of IAA includes Azospirillum sp., Alcaligenes faecalis, Klebsiella sp., Enterobacter cloacae, Acetobacter diazotrophicus, Rhizobium (Costacurta and Vanderleyden, 1995), Klebsiella oxytoca strain GR-3 (Jha and Kumar, 2007) and Pseudomonas putida (Patten and Glick, 2002). Our results are in agreement with the above reports both in terms of level of IAA production and bacterial isolates tentatively identified. Most of the agricultural soils in various parts of India contain $50 \mathrm{~kg} / \mathrm{ha}$ of phosphorous, primarily in the unavailable form of precipitated tricalcium phosphate $\left(\mathrm{Ca}_{3}\left(\mathrm{PO}_{4}\right)_{2}\right)$ in which only 2-3 ppm phosphorous is available to rice (Singh and Kapoor, 1998). Many bacteria are well known to dissolve bound phosphates such as calcium triphosphate, hydroxyapatite and rock phosphate, and enhance the availability of phosphorous for microbial and/ or plant growth (Goldstein, 1995). The highest P-solubilizing isolate ECI-12A (isolated from East Champaran district) shows 2-12 times more P-solubilizing activity than other isolates and possess all the plant growth potentials tested in this investigation seems to be a good isolate for use as biofertilizer. $\mathrm{P}$ solubilization by rhizospheric bacteria is useful character since they can partly meet $\mathrm{P}$ demand of the plants. Several workers have reported that seed or soil inoculation with phosphate-solubilizing bacteria improves solubilization of fixed soil phosphorous and/ 
or applied phosphates, resulting in higher crop yields (Singh and Kapoor, 1998).

Majority of the soil contains enough amount of iron (1-6\%) but most of them are in ferric form, which is insoluble and thus not accessible to the plants and microorganisms. Many microorganisms including bacteria and fungi have developed system for the synthesis of low molecular weight organic compounds, siderophore, which efficiently solubilize and transport ferric iron (Jadav and Desai, 1992). We have analyzed all the isolates for their iron chelating properties and observed that out of 46 isolates, 14 isolates produced siderophore in iron limiting condition. It has been demonstrated that synthesis of siderophore is induced when iron is depleted from the culture medium (Knosp et al., 1984). Our finding is in agreement with earlier report since we also observed induction under iron depleted condition. A number of diazotrophic bacteria and PGPR such as species of Pseudomonas, Azospirillum, Azotobacter, Bacillus, Klebsiella, Enterobacter, Xanthomonas and Serratia were isolated by different workers from different agro-ecosystems. All the above isolates promoted plant growth (Khalid et al., 2004). Similar to above report we also found species of Agrobacterium, Klebsiella, Microbacterium, Pseudomonas, Azotobacter and Serratia.

\section{Biochemical tests}

It is evident with the Table 3 that all isolates showed gram negative test. Motility test showed that $34(94.4 \%)$ isolates were motile and 2 (5.6\%) were non-motile. The biochemical test revealed that all the isolates were positive for catalase, however 32 (90.5\%) showed positive test for urease. Methyl red test revealed that out of 36 isolates, $20(55.5 \%)$ was methyl red positive and $16(44.5 \%)$ was negative. Simmon's citrate test showed that $30(83.4 \%)$ isolates were positive and 6 (16.6\%) was negative (Table 3). For lactose fermentation test all the isolates were grown on Mac Conkey's agar plate. Results showed that out of 36 isolates, $5(13.9 \%)$ was found positive for lactose fermentation and other 31 (84.1\%) was negative (Table 3 ).

\section{Conclusion}

In conclusion, we hereby report that species of Pseudomonas, Klebsiella, Azotobacter and Agrobacterium were predominantly present in the rhizosphere of rice plants of both districts of India. Based on their potentials for nitrogen fixation, IAA production, P- solubilization, siderophore production, their efficiency as bio-fertilizer have been checked on pot/field level trial which has been communicated for publication elsewhere.

\section{Acknowledgements}

Financial supports by ICCR, Government of India is acknowledged. The author is also grateful to Dr. Ashok Kumar, Professor, School of Biotechnology, Banaras Hindu University, Varanasi, India for guidance and all necessary facilities.

\section{References}

Benson, H.J. (1998). Microbiological applications: A laboratory manual in general microbiology, McGraw-Hill College.

Costacurta, A. \& Vanderleyden, J. (1995). Synthesis of phytohormones by plant-associated bacteria, Crit. Rev. Microbiol. 21:1-18.

Dobbelaere, S., Vanderleyden, J. \& Okon, Y. (2003). Plant growth-promoting effects of diazotrophs in the rhizosphere, Crit. Rev. Plant Sci. 22:107149.

Döbereiner, J. (1995). Isolation and identification of aerobic nitrogen-fixing bacteria from soil and plants. In: Methods in applied soil microbiology and biochemistry, Ed. K. Alef and P. Nannipieri, Academic Press, London. pp 134141.

Glick, B.R. (1995). The enhancement of plantgrowth by free-living bacteria, Can. J. Microbiol. 41:109-117. 
ISOLATION AND CHARACTERIZATION OF PLANT GROWTH PROMOTING RHIZOBACTERIA (PGPR) FROM RICE RHIZOSPHERE OF VARANASI AND EAST CHAMPARAN DISTRICT OF INDIA

Glick, B.R., Liu, C.P., Ghosh, S. \& Dumbroff, E.B. (1997). Early development of canola seedlings in the presence of the plant growth-promoting rhizobacterium Pseudomonas putida GR12-2, Soil Biol. Biochem. 29:1233-1239.

Goldstein, A.H. (1995). Recent progress in understanding the molecular-genetics and biochemistry of calcium-phosphate solubilization by gram-negative bacteria, Biol. Agric. Horti. 12:185-193.

Goldstein, A.H. \& Liu, S.T. (1987). Molecularcloning and regulation of a mineral phosphate solubilizing gene from Erwinia-herbicola, BioTechnol. 5:72-74.

Gordon, S.A. \& Weber, R.P. (1951). Colorimetric estimation of indole-acetic acid, Plant Physiol. 26:192-195.

Holt, J.G., Krieg, N.R., Sneath, P.H.A., Staley, J.T. \& Williams, S.T., (1994). Bergey's Mannual of Determinative Bacteriology ( $9^{\text {th }}$ eds), Williams and Wilkins, Baltimore, USA.

Jadav, R.S. \& Desai, A.J. (1992). Isolation and characterization of siderophore from cowpea Rhizobium (Peanut isolate), Curr. Microbiol. 24:137-141.

Jha, P.N. \& Kumar, A. (2007). Endophytic colonization of Typha australis by a plant growthpromoting bacterium Klebsiella oxytoca strain GR-3, J. Appl. Microbiol. 103:1311-1320.

Khalid, A., Arshad, M. \& Zahir, Z.A. (2004). Screening plant growth-promoting rhizobacteria for improving growth and yield of wheat, J. Appl. Microbiol. 96:473-480.

Knosp, O., Vontigerstrom, M. \& Page, W.J. (1984). Siderophore-mediated uptake of iron in Azotobacter-vinelandii, J. Bacteriol. 159:341-347.

Mehta, S. \& Nautiyal, C.S. (2001). An efficient method for qualitative screening of phosphatesolubilizing bacteria, Curr. Microbiol. 43:51-56.

Okon, Y. \& Labanderagonzalez, C.A. (1994). Agronomic applications of Azospirillum - an evalu- ation of 20 years worldwide field inoculation, Soil Biol. Biochem. 26: 1591-1601.

Patten, C.L. \& Glick, B.R. (2002). Role of Pseudomonas putida indole-acetic acid in development of the host plant root system, Appl. Environ. Microbiol. 68:3795-3801.

Schwyn, B. \& Neilands, J.B. (1987). Universal chemical assay for the detection and determination of siderophores, Anal. Biochem. 160:47-56.

Shrivastava, U. P. (2013). Isolation and initial characterization of diazotrophic plant growth promoting rhizobacteria (PGPR) from rice rhizosphere of Parsa and Bara district of Nepal. Int. J. Pharma. Life Sci. 4: 2481-2488.

Shrivastava, U. P. \& Kumar, A. (2011). A Simple and Rapid Plate Assay for the Screening of Indole-3-acetic Acid (IAA) Producing Microorganisms. Int. J. Appl. Biol. Pharma. Technol. 2: $120-123$.

Shrivastava, U. P. \& Kumar, A. (2011). Biochemical Characterization of Siderophore Producing Plant Growth Promoting Rhizobacteria (PGPR) Isolated from Rice Rhizosphere. Nep. J. Integrated Sci. 1: 31-37.

Singh, S. \& Kapoor, K.K. (1998). Effects of inoculation of phosphate-solubilizing microorganisms and an arbuscular mycorrhizal fungus on mungbean grown under natural soil conditions, Mycorrhiza 7:249-253.

Stewart, W.D., Fitzgerald, G.P. \& Burris, R.H., (1967). In situ studies on $\mathrm{N}_{2}$ fixation using the acetylene reduction technique, Proc. Nat. Acad. Sci. 58:2071-2078.

Timmusk, S, Nicander, B., Granhall, U. \& Tillberg, E. (1999). Cytokinin production by Paenibacillus polymyxa, Soil Biol. Biochem. 31:1847-1852.

Zambryski, P., Tempe, J. \& Schell, J. (1989). Transfer and function of t-DNA genes from Agrobacterium TI-plasmid and RI-plasmid in plants, Cell 56:193-201. 
Umesh Prasad Shrivastava

Table 1: Details of sample collection sites showing their coordinate (Latitude \& Longitude) and CFU/g of soil sample.

\begin{tabular}{|c|c|c|c|c|}
\hline $\begin{array}{l}\text { Sample } \\
\text { ID }\end{array}$ & Locality of collection & $\begin{array}{c}\text { (Latitude } \& \\
\left.\text { Longitude } \pm 1 . \mathbf{o}^{\prime}\right)\end{array}$ & $\begin{array}{c}\text { Colony forming } \\
\text { units/g soil }\end{array}$ & $\begin{array}{c}\text { No. of } \\
\text { Isolates }\end{array}$ \\
\hline ECI-1 & Semara & $26^{\circ} 62^{\prime} \mathrm{o}^{\prime \prime} \mathrm{N}, 84^{\circ} 52^{\prime} \mathrm{o} " \mathrm{E}$ & $28 \times 10^{6}$ & 1 \\
\hline ECI-2 & Semara & $26^{\circ} 62^{\prime} \mathrm{o}^{\prime \prime} \mathrm{N}, 84^{\circ} 52^{\prime} \mathrm{o} " \mathrm{E}$ & $64 \times 10^{5}$ & 1 \\
\hline $\mathrm{ECI}-5$ & Chapawa bahas & $26^{\circ} 64^{\prime} \mathrm{N}, 84^{\circ} 52^{\prime} \mathrm{E}$ & $26.1{\mathrm{X} 10^{4}}^{4}$ & 2 \\
\hline ECI-6 & Chapawa bahas & $26^{\circ} 64^{\prime} \mathrm{N}, 84^{\circ} 52^{\prime} \mathrm{E}$ & $27{\mathrm{X} 10^{4}}^{4}$ & 3 \\
\hline ECI-7 & Gamharia Kala & $26^{\circ} 60^{\prime \prime o " N}, 84^{\circ} 48^{\prime} \mathrm{o}^{\prime \prime} \mathrm{E}$ & $10.6 \times 10^{4}$ & 3 \\
\hline ECI-8 & Gamharia Kala & $26^{\circ} 60^{\prime o " N}, 84^{\circ} 48^{\prime \prime o " E}$ & $11.5{\mathrm{X} 10^{4}}^{4}$ & 2 \\
\hline ECI-9 & Bahadurpur & $26^{\circ} 60^{\prime} \mathrm{o}^{\prime \prime N}, 84^{\circ} 46^{\prime} \mathrm{o} " \mathrm{E}$ & $8 \times 10^{5}$ & 3 \\
\hline ECI-10 & Gamharia Kala & $26^{\circ} 60^{\prime}$ o"N, $84^{\circ} 48^{\prime}$ o"E & $10.2 \times 10^{5}$ & 3 \\
\hline ECI-11 & Bahadur Pur & $26^{\circ} 60^{\prime} \mathrm{o}^{\prime \prime N}, 84^{\circ} 46^{\prime} \mathrm{o}^{\prime \prime} \mathrm{E}$ & $10.1{\mathrm{X} 10^{4}}^{4}$ & 2 \\
\hline ECI-12 & Gamharia Kala & $26^{\circ} 60^{\prime o} \mathrm{o} \mathrm{N}, 84^{\circ} 48^{\prime} \mathrm{o} " \mathrm{E}$ & $117{\mathrm{X} 10^{5}}^{5}$ & 3 \\
\hline ECI-13 & Bahadur pur & $26^{\circ} 60^{\prime} \mathrm{o}^{\prime \prime N}, 84^{\circ} 46^{\prime} \mathrm{o} " \mathrm{E}$ & $18.9 \times 10^{4}$ & 3 \\
\hline AF-1 & B.H.U. Agricultures Farm & $25^{\circ} 33^{\prime} \mathbf{o}^{\prime \prime N}, 83^{\circ} \mathrm{o}^{\prime} \mathbf{o}^{\prime \prime E}$ & $7.8 \times 10^{4}$ & 4 \\
\hline $\mathrm{AF}-3$ & B.H.U. Agricultures Farm & $25^{\circ} 33^{\prime} \mathbf{0} " \mathrm{~N}, 83^{\circ} \mathrm{o}^{\prime}$ o"E & $133 \times 10^{4}$ & 5 \\
\hline $\mathrm{AF}-4$ & B.H.U. Agricultures Farm & $25^{\circ} 33^{\prime} \mathbf{o}^{\prime \prime N}, 83^{\circ} \mathrm{o}^{\prime} \mathbf{o}^{\prime \prime} \mathrm{E}$ & $69 \times 10^{4}$ & 2 \\
\hline $\mathrm{AF}-5$ & B.H.U. Agricultures Farm & $25^{\circ} 33^{\prime} \mathbf{o}^{\prime \prime N}, 83^{\circ} \mathrm{o}^{\prime} \mathbf{o}^{\prime \prime E}$ & $206{\mathrm{X} 10^{4}}^{4}$ & 3 \\
\hline AF-6 & B.H.U. Agricultures Farm & $25^{\circ} 33^{\prime} \mathbf{o}^{\prime \prime} \mathrm{N}, 83^{\circ} \mathrm{o}^{\prime} \mathbf{o}^{\prime \prime} \mathrm{E}$ & $172{\mathrm{X} 10^{4}}^{4}$ & 3 \\
\hline AF-7 & B.H.U. Agricultures Farm & $25^{\circ} 33^{\prime} \mathbf{0} " \mathrm{~N}, 83^{\circ} \mathrm{o}^{\prime} \mathbf{0} " \mathrm{E}$ & $178 \times 10^{4}$ & 3 \\
\hline
\end{tabular}

ECI- East Champaran India, ECI- (1-13) - refers to different isolates of East Champaran, India. AF- (1-7) isolates from Agriculture farm (B.H.U.) of Varanasi. India

Table 2: Rate of nitrogenase activity, iaa production, $p$ solubilization and siderophore production in various isolates

\begin{tabular}{|c|c|c|c|c|}
\hline Isolate & $\begin{array}{l}\text { Nitrogenase activity } \\
\left(\mu \mathrm{mol} \mathrm{C}_{2} \mathrm{H}_{4} / \mathrm{mg} \text { protein } / \mathrm{h}\right)\end{array}$ & $\begin{array}{l}\text { IAA production } \\
(\mu \mathrm{g} / \mathrm{mg} \text { dry weight })\end{array}$ & $\begin{array}{l}\text { P solubilization } \\
\text { ( } \mu \mathrm{g} / \mathrm{mg} \text { dry weight) }\end{array}$ & $\begin{array}{l}\text { Siderophore } \\
\text { production } \\
(\mu \mathrm{g} / \mathrm{mg} \text { dry weight })\end{array}$ \\
\hline ECI-1A & $1.12 \pm 0.13$ & $4.80 \pm 0.4$ & - & $17.9 \pm 2.86$ \\
\hline ECI-1B & $0.78 \pm 0.09$ & $3.57 \pm 0.5$ & - & $12.13 \pm 2.54$ \\
\hline ECI-2A & $0.62 \pm 0.08$ & $1.75 \pm 0.6$ & $92.13 \pm 3.5$ & - \\
\hline ECI-2B & $0.69 \pm 0.07$ & $1.78 \pm 0.3$ & $16.04 \pm 4.6$ & - \\
\hline ECI-5B & $0.78 \pm 0.16$ & - & $140.06 \pm 9.5$ & - \\
\hline ECI-5C & $0.84 \pm 0.14$ & - & - & - \\
\hline ECI-6A & $0.81 \pm 0.09$ & $3.10 \pm 0.4$ & - & - \\
\hline ECI-6B & $0.94 \pm 0.08$ & - & - & - \\
\hline ECI-6C & $0.93 \pm 0.11$ & $2.85 \pm 0.5$ & - & - \\
\hline ECI-7A & $0.68 \pm 0.09$ & $2.93 \pm 0.45$ & $52.88 \pm 8.4$ & - \\
\hline ECI-7B & $0.71 \pm 0.08$ & - & - & - \\
\hline
\end{tabular}


ISOLATION AND CHARACTERIZATION OF PLANT GROWTH PROMOTING RHIZOBACTERIA (PGPR) FROM RICE RHIZOSPHERE OF VARANASI AND EAST CHAMPARAN DISTRICT OF INDIA

Table 2 continue...

\begin{tabular}{|c|c|c|c|c|}
\hline Isolate & $\begin{array}{l}\text { Nitrogenase activity } \\
\left(\mu \mathrm{mol} \mathrm{C}_{2} \mathrm{H}_{4} / \mathrm{mg} \text { protein } / \mathrm{h}\right)\end{array}$ & $\begin{array}{l}\text { IAA production } \\
(\mu \mathrm{g} / \mathrm{mg} \text { dry weight })\end{array}$ & $\begin{array}{l}\text { P solubilization } \\
(\mu \mathrm{g} / \mathrm{mg} \text { dry weight })\end{array}$ & $\begin{array}{l}\text { Siderophore } \\
\text { production } \\
\text { ( } \mu \mathrm{g} / \mathrm{mg} \text { dry weight) }\end{array}$ \\
\hline ECI-7C & $0.75 \pm 0.08$ & $3.11 \pm 0.35$ & - & - \\
\hline \begin{tabular}{|l} 
ECI-7D \\
\end{tabular} & $0.94 \pm 0.09$ & - & $16.04 \pm 4.2$ & - \\
\hline ECI-8B & $0.62 \pm 0.14$ & - & - & - \\
\hline ECI-9A & $0.69 \pm 0.07$ & - & $12.9 \pm 2.9$ & $12.87 \pm 3.25$ \\
\hline ECI-9B & $0.76 \pm 0.19$ & - & $40.37 \pm 3.5$ & $11.38 \pm 2.45$ \\
\hline ECI-9C & $0.69 \pm 0.14$ & - & - & - \\
\hline ECI-10A & $1.72 \pm 0.09$ & $5.35 \pm 0.42$ & $13.25 \pm 5.5$ & $20.04 \pm 3.57$ \\
\hline ECI-10B & $0.73 \pm 0.08$ & $4.99 \pm 0.5$ & - & $20.43 \pm 3.94$ \\
\hline ECI-10C & $0.75 \pm 0.09$ & - & - & - \\
\hline ECI-11A & $0.73 \pm 0.17$ & - & - & - \\
\hline ECI-11C & $0.67 \pm 0.09$ & $5.78 \pm 0.6$ & $40.0 \pm 10.25$ & - \\
\hline ECI-12A & $1.35 \pm 0.25$ & $2.4 \pm 0.25$ & $188.65 \pm 8.65$ & - \\
\hline ECI-12B & $1.25 \pm 0.18$ & $2.35 \pm 0.35$ & - & - \\
\hline ECI-12C & $0.88 \pm 0.8$ & $3.68 \pm 0.4$ & - & - \\
\hline ECI-13B & $0.74 \pm 0.09$ & - & - & - \\
\hline ECI-13C & $0.62 \pm 0.08$ & - & - & - \\
\hline ECI-13D & $0.83 \pm 0.11$ & - & - & - \\
\hline AF-1A & $0.73 \pm 0.15$ & $4.03 \pm 0.4$ & - & $18.66 \pm 1.65$ \\
\hline AF-1B & $0.74 \pm 0.09$ & $4.63 \pm 0.6$ & - & $16.62 \pm 2.36$ \\
\hline AF-1C & $0.96 \pm 0.14$ & $4.08 \pm 0.55$ & $12.47 \pm 3.5$ & - \\
\hline AF-1D & $1.41 \pm 0.06$ & $6.57 \pm 0.6$ & $12.74 \pm 4.6$ & $15.84 \pm 2.55$ \\
\hline $\mathrm{AF}-3 \mathrm{~B}$ & $0.82 \pm 0.15$ & $6.6 \pm 0.45$ & - & - \\
\hline $\mathrm{AF}-3 \mathrm{C}$ & $0.65 \pm 0.16$ & $6.26 \pm 0.8$ & - & - \\
\hline $\mathrm{AF}-4^{\mathrm{B}}$ & $1.53 \pm 0.14$ & $2.3 \pm 0.3$ & $18.05 \pm 4.3$ & $1.45 \pm 2.32$ \\
\hline $\mathrm{AF}-4 \mathrm{C}$ & $1.65 \pm 0.15$ & $5.7 \pm 0.6$ & $14.08 \pm 5.2$ & $9.59 \pm 1.55$ \\
\hline $\mathrm{AF}-5 \mathrm{~A}$ & $1.38 \pm 0.09$ & $6.69 \pm 0.6$ & $17.71 \pm 4.8$ & $9.66 \pm 2.28$ \\
\hline $\mathrm{AF}-5 \mathrm{C}$ & $0.94 \pm 0.06$ & $6.85 \pm 0.7$ & - & $9.59 \pm 2.95$ \\
\hline$A F-5 D$ & $0.96 \pm 0.12$ & - & $34.45 \pm 5.8$ & $18.9 \pm 2.38$ \\
\hline AF-6A & $0.79 \pm 0.08$ & $7.35 \pm 0.8$ & - & - \\
\hline AF-6B & $0.77 \pm 0.07$ & $4.55 \pm 0.9$ & - & - \\
\hline AF-6D & $0.88 \pm 0.09$ & $4.3 \pm 0.4$ & - & - \\
\hline AF-7A & $0.86 \pm 0.11$ & $2.93 \pm 0.5$ & - & - \\
\hline$A F-7 B$ & $1.14 \pm 0.23$ & $3.38 \pm 0.64$ & - & - \\
\hline $\mathrm{AF}-7 \mathrm{C}$ & $1.32 \pm 0.24$ & $7.36 \pm 0.38$ & - & - \\
\hline AF-7D & $0.98 \pm 0.08$ & $2.95 \pm 0.45$ & - & - \\
\hline
\end{tabular}

\# Nitrogenase activity was tested in JNFb semi-solid (0.15\%) medium. Cultures were preincubated for $6 \mathrm{~h}$ with $\mathrm{C}_{2} \mathrm{H}_{2}$ for estimation of $\mathrm{C}_{2} \mathrm{H}_{4}$ formation.

\# For IAA production, cultures were grown in JNFb-liquid medium containing $100 \mu \mathrm{g} / \mathrm{mL}$ tryptophan for 3 days and thereafter IAA estimation was made.

\# P solubilization was tested after 3 days of growth in Nautiyal liquid medium.

\# Siderophore was estimated after 3 days growth of culture in JNFb-liquid medium containing $2 \mu \mathrm{M}$ of $\mathrm{FeCl}_{3}$ in place of $\mathrm{Fe}$-EDTA.

\# Results are based on average of two experiments conducted under identical conditions \pm 


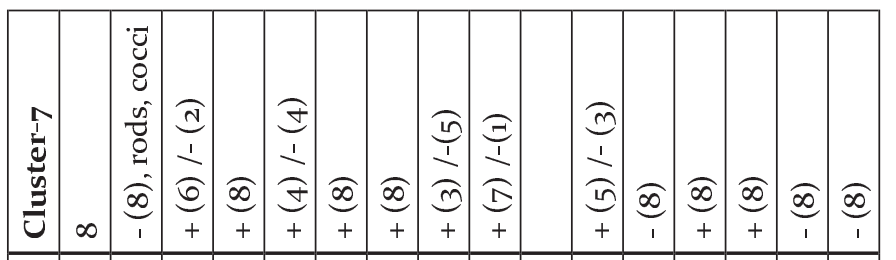

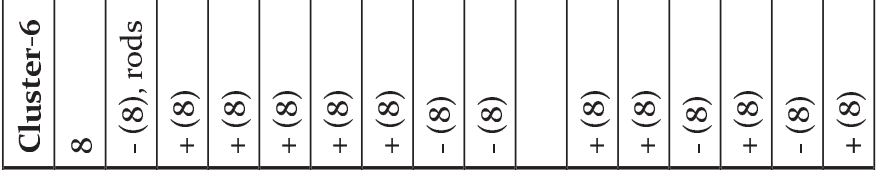

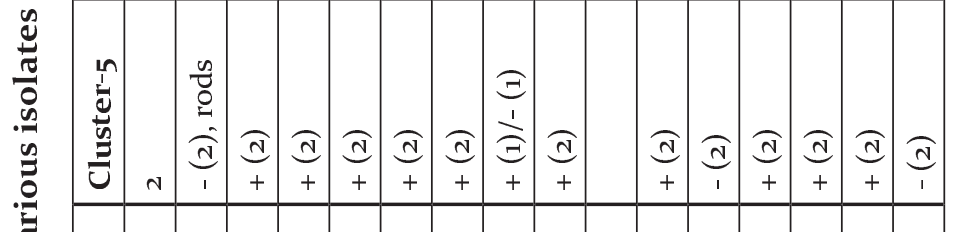

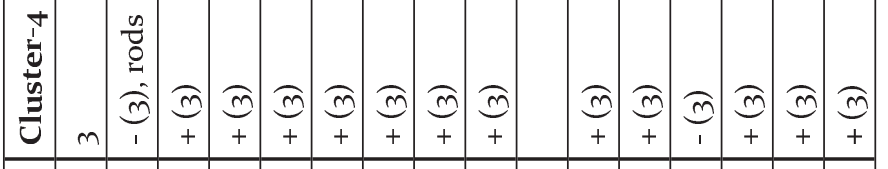

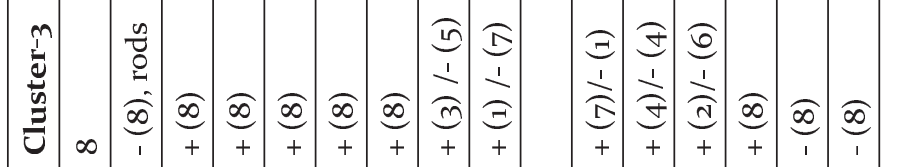
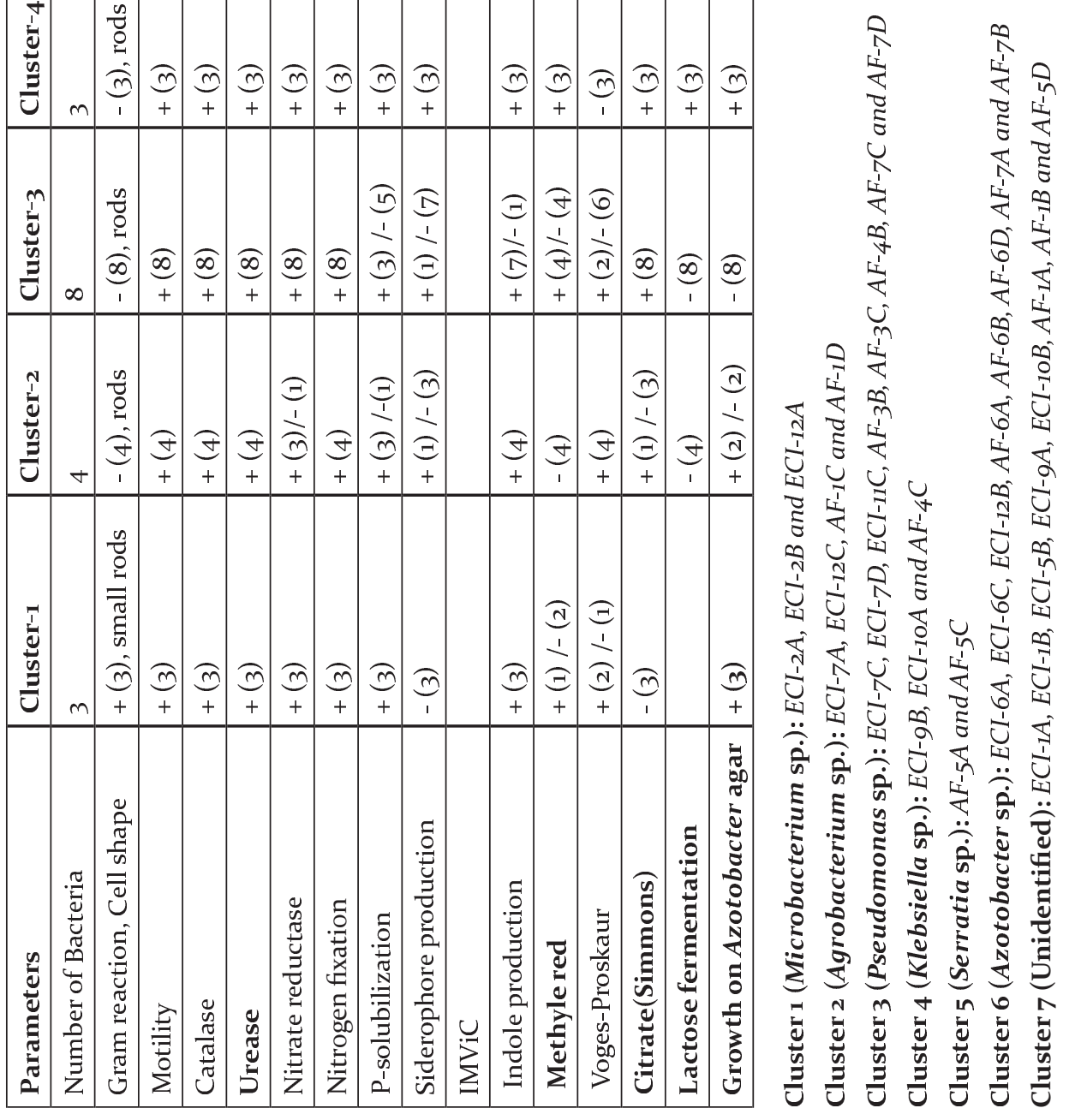

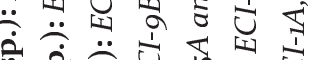
है के के 